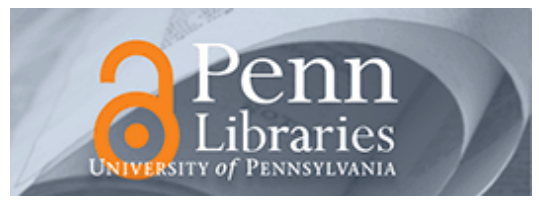

University of Pennsylvania

ScholarlyCommons

Management Papers

Wharton Faculty Research

8-1997

\title{
Spillovers, Foreign Investment, and Export Behavior
}

Brian J. Aitken

Gordon Hanson

Ann E. Harrison

University of Pennsylvania

Follow this and additional works at: https://repository.upenn.edu/mgmt_papers

Part of the Business Administration, Management, and Operations Commons, Marketing Commons, and the Sales and Merchandising Commons

\section{Recommended Citation}

Aitken, B. J., Hanson, G., \& Harrison, A. E. (1997). Spillovers, Foreign Investment, and Export Behavior. Journal of International Economics, 43 (1-2), 103-132. http://dx.doi.org/10.1016/S0022-1996(96)01464-X

This paper is posted at ScholarlyCommons. https://repository.upenn.edu/mgmt_papers/10

For more information, please contact repository@pobox.upenn.edu. 


\title{
Spillovers, Foreign Investment, and Export Behavior
}

\begin{abstract}
Case studies of export behavior suggest that firms that penetrate foreign markets reduce entry costs for other potential exporters, either through learning effects or establishing commercial linkages. We examine whether spillovers associated with one firm's export activity reduce the cost of exporting for other firms. We identify two sources of spillovers: export production in general and the specific activities of multinationals. From a simple model of export behavior we derive a probit specification for the probability that a firm exports. Using panel data on Mexican manufacturing plants, we find evidence of spillovers from multinational enterprises but not from general export activity.
\end{abstract}

\section{Keywords}

multinational enterprises, geographic concentration of industry, export production

\section{Disciplines}

Business Administration, Management, and Operations | Marketing | Sales and Merchandising 
NBER WORKING PAPER SERIES

\title{
SPILLOVERS, FOREIGN INVESTMENT, AND EXPORT BEHAVIOR
}

\author{
Brian Aitken
}

Gordon H. Hanson

Ann E. Harrison

Working Paper No. 4967

\section{NATIONAL BUREAU OF ECONOMIC RESEARCH 1050 Massachusetts Avenue \\ Cambridge, MA 02138 \\ December 1994}

The authors thank seminar participants at the 1994 NBER Summer Institute on International Trade and Investment for valuable comments. This research was supported by World Bank research project 678-29, "Technology Spillovers, Agglomeration, and Direct Foreign Investment." This paper is part of NBER's research program in International Finance and Macroeconomics. Any opinions expressed are those of the authors and not those of the National Bureau of Economic Research.

(ㄷ) 1994 by Brian Aitken, Gordon H. Hanson and Ann E. Harrison. All rights reserved. Short sections of text, not to exceed two paragraphs, may be quoted without explicit permission provided that full credit, including $\odot$ notice, is given to the source. 


\title{
SPILLOVERS, FOREIGN INVESTMENT, AND EXPORT BEHAVIOR
}

\begin{abstract}
Case studies of export behavior suggest that firms who penetrate foreign markets reduce entry costs for other potential exporters, either through learning by doing or through establishing buyer-supplier linkages. We pursue the idea that spillovers associated with one firm's export activity reduce the cost of foreign market access for other firms. We identify two potential sources of spillovers: export activity in general and the specific activities of multinational enterprises. We use a simple model of export behavior to derive a logit specification for the probability a firm exports. Using panel data on Mexican manufacturing plants, we find evidence consistent with spillovers from the export activity of multinational enterprises but not with general export activity.
\end{abstract}

Brian Aitken

International Monetary Fund

700 19th Street, NW

Washington, DC 20431

Ann E. Harrison

Graduate School of Business

Columbia University

615 Uris Hall

New York, NY 10027

and NBER
Gordon H. Hanson

Department of Economics

University of Texas

Austin, TX 78712

and NBER 


\section{Introduction}

What explains the export behavior of firms? Trade theory has little to say about which firms in a country export and which produce for the domestic market, and there has been little formal empirical work on the subject. ${ }^{1}$ Anecdotal evidence, mostly derived from case studies in developing countries, suggests that the process of breaking into foreign markets is far from trivial (Morawetz 1981, Kessing 1983).

One of the most spectacular case studies of export growth, the development of garment exporters in Bangladesh, suggests that informational externalities are likely to be extremely important. The entry of one Korean garment exporter in Bangladesh led to the establishment of hundreds of exporting enterprises, all owned by local entrepreneurs. Garment exports, which accounted for a negligible percentage of total export earnings, became the single largest source of foreign exchange earnings after the entry of one multinational firm.

The idea we pursue in this paper is that there are localized spillovers associated with exporting by one firm that reduce the cost of foreign market access for nearby firms. We consider two versions of the export-spillovers hypothesis: (1) all export activity generates spillovers, and (2) only the export activity of multinational enterprises generates spillovers.

Spillovers may take a variety of forms. The geographic concentration of exporters may make it feasible to construct specialized transportation infrastructure, such as storage facilities or rail lines, or may improve access to information about which goods are popular among foreign consumers. Whatever their source, spillovers imply that there are location-specific external economies associated with exporting. This means that firms are more likely to export

\footnotetext{
' One exception is Roberts and Tybout (1993), who find evidence of sunk costs in the export supply decision.
} 
the larger is the local concentration of export activity. The potential for spillovers from multinational enterprises (MNEs) derives from the fact that foreign firms have a multi-market presence. MNEs are a natural conduit for information about foreign markets, consumers, and technology, and provide a natural channel through which domestic firms can distribute their goods. To the extent that MNEs directly or indirectly provide information and distribution services, their activities enhance the export prospects of local firms.

There is a growing body of empirical work which claims to find evidence consistent with spillovers. ${ }^{2}$ A standard approach for identifying the effects of spillovers on the production decisions of individual firms is to use a measure of aggregate local industrial activity, such as employment or value added, as an independent variable. The general hypothesis is that the larger is the local concentration of economic activity, the larger are the benefits derived from spillovers. Carlton (1983) finds that the geographic concentration of firms in an industry makes a location more attractive to entering firms; Nakamura (1985) and Henderson (1986) find that geographic concentration is positively correlated with total factor productivity; and Wheeler and Mody (1992) and Head and Ries (1994) find the local stock of foreign investment is a positive factor in the location decision of MNEs. These findings are interpreted as evidence of spillovers, but it is just as plausible to interpret them as evidence of unobserved fixed factors that firms value. The confusion is due to a basic identification problem: geographic concentration arising from location-specific external economies is observationally equivalent to geographic concentration arising from exogenous site-specific characteristics.

2 The externalities we take as our focus are static in nature. There is a growing empirical literature on dynamic externalities of the sort consistent with recent theories of endogenous growth. Glaeser et al. (1992), Jaffe, Trajtenberg, and Henderson (1993), and Henderson (1994) are influential contributions. 
The contribution of our approach is that we address the identification problem by decomposing the geographic concentration of industry into different elements. We are able to independently measure for each location the overall concentration of economic activity, the concentration of export activity, and the concentration of MNE export activity. We control for unobserved fixed factors that might affect the export behavior of firms by controlling for the overall concentration of activity in a location. If the local concentration of export activity is just a byproduct of overall industry concentration, then we will find that local export activity and local MNE activity do not affect the firm export decision. If, on the other hand, there are spillovers specific to exporting or to MNEs, then we will find that the local activities of other exporters or of MNEs positively influence the firm export decision. ${ }^{3}$

The role of MNEs in developing countries has received considerable attention. Most recent literature considers MNEs as a direct or indirect source of foreign technology. The proposed benefits of FDI include technological diffusion (Davies 1977, Teece 1977), worker training (Gonclaves 1986), and the expansion of producer services (Rivera-Batiz and RiveraBatiz 1991). Empirical studies that use aggregate data (Caves 1974, Blomstrom and Persson 1983, Blomstrom 1986) find a positive correlation between sectoral productivity and the sectoral level of FDI; but studies that use plant-level data (Aitken and Harrison 1993, Haddad and Harrison 1993) find either a negative correlation or no relationship between the presence of MNEs and the productivity of domestically-owned manufacturing plants.

The hypothesis we test is that MNEs act as export catalysts. Case studies suggest that the export activities of MNEs can produce externalities which enhance the export prospects of

\footnotetext{
${ }^{3}$ Our approach is similar in spirit to that of Head, Ries, and Swenson (1993), who study the location decisions of Japanese multinationals.
} 
domestic firms (Rhee and Belot 1990). By providing inputs not available in the local market, MNEs link local firms to foreign buyers. While they may internalize some of the benefits of their activities through subcontracting or licensing arrangements, other effects, such as those related to demonstration or expanded cross-border trade, are more difficult to internalize, and may spill over onto neighboring firms. While there is much anecdotal evidence identifying spillovers from MNEs, there has been no study which formally tests the role of foreign firms as export catalysts, or determines the importance of this role in the economy at large.

The basis for our study is panel data on 2,113 Mexican manufacturing plants. The sample covers the period 1986-1990, which follows Mexico's liberalization of trade in $1985 .^{4}$ We observe the period when many Mexican manufacturers first began to insert themselves into foreign markets. We develop a simple model of the firm production decision and derive a reduced form for the probability a firm exports. If there are spillovers associated with exporting, a firm will be more likely to export the larger is the local concentration of export activity; if there are spillovers associated with the specific activities of MNEs, a firm will be more likely to export the larger is the local concentration of exports by MNEs.

\section{An Empirical Model}

\section{A. Theory}

In the production decision we model, firms choose whether to serve the domestic market, the foreign market, or both. Although firms have the option of exporting to multiple markets, for simplicity we treat foreign markets as a single entity. We assume the distribution costs of

4 Trade liberalization in Mexico ended four decades of import-substitution industrialization. The country initiated reform in 1985 and by 1988 had eliminated, or at least drastically reduced, most trade barriers. 
producing for the domestic market differ from those of producing for the foreign market. For a representative firm, total costs are given by

$$
\text { (1) } h\left(q_{d}+q_{f}\right)+m_{d}\left(q_{d}\right)+m_{f}\left(q_{f}\right)
$$

where $d$ indexes the domestic market, $f$ indexes the foreign market, $h()$ is the production cost function, $m_{i}()$ is the distribution cost function for market $i$, and $h()$ and $m_{i}()$ are increasing and convex in their arguments. Separating production and distribution costs captures the idea that some costs, such as those related to design, advertising, and transportation, are market specific.

The central hypothesis in our empirical work is that market-specific costs in exporting are a decreasing function of the local concentration of export activity. Very simply, we suppose that exporters benefit from being near other exporters. Let $\Gamma_{E X}$ be total export activity and $\Gamma_{M N E}$ be the export activity of MNEs in the regional industry to which a firm belongs. Positive export spillovers imply that for the representative firm,

$$
\begin{aligned}
& \text { (2) } \frac{\delta m_{f}\left(g_{f}\right)}{\delta \Gamma_{E x}} \leq 0 \\
& \text { (3) } \frac{\delta m_{f}\left(g_{f}\right)}{\delta \Gamma_{M N E}} \leq 0
\end{aligned}
$$

We leave to section IV the discussion of how we measure $\Gamma_{E X}$ and $\Gamma_{M N E}$.

For empirical tractability, we assume a simple functional form for the cost function,

$$
h\left(q_{d}+q_{f}\right)=\frac{a}{2}\left(q_{d}+q_{f}\right)^{2}, \quad m_{i}\left(q_{i}\right)=\frac{b_{i}}{2}{q_{i}}^{2}+c_{i} q_{i}
$$

where $a$ and $b_{i}$ are parameters and $c_{i}$ is a function of cost variables the firm takes as given in making the supply decision. In particular, $c_{i}$ is a function of factor prices and the characteristics of a location that matter for costs: 


$$
c_{d}=c_{d}\left(X, z_{d}\right), \quad c_{f}=c_{f}\left(X, z_{f}, \Gamma_{E X}, \Gamma_{M N E}\right)
$$

where $X$ represents cost variables that are common to production for both markets, and $Z_{i}$ represents cost variables that are specific to production for market $i$. The specification of market-specific costs implies that export spillovers do not affect the costs of serving the domestic market. We discuss this issue in more detail below.

The production decision for the representative firm is given by the solution to

$$
\text { (4) } \max _{q_{d}, q_{t}} P_{d} q_{d}+P_{f} q_{f}-h\left(q_{d}+q_{f}\right)-m_{d}\left(q_{d}\right)-m_{f}\left(q_{f}\right) \quad \text { s.t. } q_{d}, q_{f} \geq 0
$$

From the first-order conditions to (4), we obtain the following system:

$$
\begin{gathered}
\text { (5) } q_{d}=\frac{1}{a+b_{d}}\left(P_{d}-a q_{f}-c_{d}\left(X, z_{d}\right)\right) \\
\text { (6) } q_{f}=\frac{1}{a+b_{f}}\left(P_{f}-a q_{d}-c_{f}\left(X, z_{f}, \Gamma_{E X}, \Gamma_{\text {LNE }}\right)\right)
\end{gathered}
$$

From (2) and (3), it follows that $q_{f}$ is increasing in $\Gamma_{E X}$ and $\Gamma_{M N E}$.

In the sample of manufacturing plants we study, all plants have positive sales on the domestic market $\left(q_{d}>0\right)$, but not all plants have positive exports $\left(q_{f} \geq 0\right)$. For some firms, then, the constraint on $q_{f}$ is binding. From the perspective of the econometrician, this implies the observations on $q_{f}$ are censored at 0 , which creates several issues for estimation. To deal with censoring explicitly, we define the latent variable $q_{f}^{*}$, where $j$ indexes the firm,

$$
\text { (7) } \begin{aligned}
q_{f j}^{*} & =q_{f j} & & \text { if } q_{f j}>0 \\
q_{f j}^{*} & =0 & & o / w
\end{aligned}
$$

For purposes of estimation, we assume expressions (5) and (6) can be rewritten as where $Z_{i j}$ is a $1 \times \mathrm{K}$ vector of cost variables that are specific to market $i, X_{j}$ is a $1 \times \mathrm{J}$ vector of cost variables that are common to both markets, $\alpha_{3}$ and $\beta_{3}$ are $1 \times \mathrm{K}$ vectors of coefficients, $\alpha_{4}$ 


$$
\begin{gathered}
\text { (8) } q_{d j}=\alpha_{1} P_{d}+\alpha_{2} q^{*}{ }_{f j}+\alpha_{3}{ }^{\prime} Z_{d j}+\alpha_{4}{ }^{\prime} X_{j}+u_{d j} \\
\text { (9) } q^{*}{ }_{f j}=\beta_{1} P_{f}+\beta_{2} q_{d j}+\beta_{3}{ }^{\prime} Z_{f j}+\beta_{4}{ }^{\prime} X_{j}+\beta_{5} \Gamma_{E X j}+\beta_{6} \Gamma_{M N E j}+u_{f j}
\end{gathered}
$$

and $\beta_{4}$ are $1 \times \mathrm{J}$ vectors of coefficients, and $u_{i j}$ is an error term associated with market $i$ and firm $j$. From (5) and (6), it follows that $\alpha_{2}$ and $\beta_{2}$ are negative.

Expressions (8) and (9) represent a simultaneous-equation model with a censored variable. The estimation techniques for such problems are straightforward, but have one major drawback. It is difficult to treat panel data problems, such as the existence of a firm-specific fixed effect. Given the structure of the problem, we choose a simple alternative method for estimating the probability that a firm chooses to export. By estimating the dummy variable $y_{j}$,

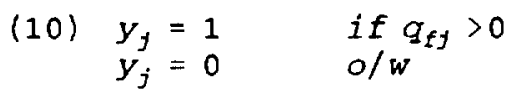

which indicates whether or not a firm has positive exports, we obtain consistent estimates of the parameters in equations (8) and (9). It is straightforward to show that the probability firm $j$ has positive exports is given by

$$
\text { (11) } \begin{aligned}
\operatorname{Pr}\left(y_{j}=1\right)= & \operatorname{Pr}\left[\boldsymbol{\beta}_{1} P_{f}+\boldsymbol{\beta}_{2}\left(\alpha_{1} P_{d}+\alpha_{3}{ }^{\prime} Z_{d j}\right)+\beta_{3}{ }^{\prime} Z_{f j}+\left(\beta_{2} \alpha_{4}{ }^{\prime}+\beta_{4}{ }^{\prime}\right) X_{j}\right. \\
& \left.+\beta_{5} \Gamma_{E X j}+\beta_{6} \Gamma_{M N B j}+\beta_{2} u_{d j}+u_{f j}>0\right]
\end{aligned}
$$

Equation (11) shows that the probability of exporting is a function of domestic and foreign finalgoods prices, cost variables common to both markets $\left(X_{j}\right)$, market-specific cost variables $\left(Z_{d j}\right.$ and $\left.Z_{f}\right)$, and the local concentration of export activity $\left(\Gamma_{E X}\right.$ and $\left.\Gamma_{M N E}\right)$. We assume that $u_{i j}$ for all $i$ and $j$ is distributed iid according to the extreme value distribution, which permits estimation of (11) as a binary logit. The logit assumption is useful for fixed-effects estimation.

\section{B. Estimation Issues}


Several estimation issues merit further discussion. The first is whether we can identify in expression (11) the effects of spillovers on the export decision. Suppose that, contrary to our model, spillovers are not specific to exporting. That is, firms benefit from being near other firms in their industry, regardless of which markets these firms serve. In this case, if $\Gamma_{E X}$ and $\Gamma_{M N E}$ are correlated with the geographic concentration of activity in an industry, then what the coefficients $\beta_{5}$ and $\beta_{6}$ will capture is not the effects of export spillovers but the effects of general spillovers. To control for the possibility, we include as a regressor a measure of the geographic concentration of overall economic activity in the industry.

A related identification problem arises from the possibility that spillovers associated with exporting may act to reduce domestic production and distribution costs as well. If export spillovers affect both foreign and domestic costs, then the "true" expression for $q_{d}$ in (8) contains the additional right-hand-side term, $\alpha_{5} \Gamma_{E X}+\alpha_{6} \Gamma_{\mathrm{MNE}}$, and the "true" expression for the probability a firm exports in (11) contains the additional term, $\beta_{2}\left(\alpha_{5} \Gamma_{E X}+\alpha_{6} \Gamma_{M N E}\right)$. Consider the coefficient estimate on the variable, $\Gamma_{M N E}$. In expectation, the coefficient estimate will equal $\beta_{6}+\beta_{2} \alpha_{6}$. If there are positive spillovers from MNE export activity, then $\alpha_{6}$ and $\beta_{6}$ will be positive, but, since $\beta_{2}$ is negative, the coefficient for $\Gamma_{\mathrm{MNE}}$ will have an ambiguous sign. A sufficient condition for the estimated coefficient on $\Gamma_{\mathrm{MNE}}$ to be positive is that $\beta_{6}>-\beta_{2} \alpha_{6}$, which will hold as long as the cost-reducing effects of MNE activity on export production exceed the cost-reducing effects of MNE activity on domestic production by a sufficient amount. An analogous condition holds for the variable, $\Gamma_{E X}$. In other words, the possibility that aggregate export activity also reduces the cost of producing for the domestic market leads to a downward bias in our spillover parameter. 
A final issue is the possibility that the variables, $\Gamma_{E X}$ and $\Gamma_{M N E}$, are determined simultaneously with the export decisions of individual firms. We treat the local concentration of export activity as exogenous, since the firm takes it as given. There are several instances in which the assumption is unwarranted. Suppose that the export decision is a function of the exogenous characteristics of a location. Baja California, for instance, is good place to export shrimp to the United States because it is has coastal access and it is located near the MexicoU.S. border. Such characteristics amount to unobserved plant-specific effects. Chamberlain (1980) shows that logit estimation with fixed effects leads to biased coefficient estimates. A further problem is that since location effects affect the export decision of all firms in a regional industry, $\Gamma_{E X}$ and $\Gamma_{M N E}$ will also be functions of these characteristics, introducing an additional source of bias into the estimation. In a linear regression framework, unobserved fixed effects can be removed by first-differencing the data. In a logit framework, Chamberlain shows that an analogous solution applies. Further, if $\Gamma_{E X}$ and $\Gamma_{M N E}$ are linear functions of the fixed effects, then Chamberlain's quasi-first-differencing approach eliminates both sources of bias. To deal with this issue, we estimate both fixed-effect and non-fixed-effect versions of (11).

A second potential source of simultaneity bias is the existence of shocks to firm costs, where the shocks contain a component that is both industry and location specific. In this case, the export decision will be correlated with $\Gamma_{E X}$ and $\Gamma_{M N E}$, not because there are positive export spillovers, but because all three variables are functions of the same cost innovation. To the extent cost shocks are uncorrelated over time, we can solve the problem by using lagged values of $\Gamma_{E X}$ and $\Gamma_{M N E}$ as regressors. This is the approach we take. 


\section{The Data}

\section{A. Data Sources}

The data are drawn from two sources. We have annual data on 2,113 Mexican manufacturing plants for the period 1986 to 1990 from the Secretariat of Trade and Industrial Promotion (Secofi). The variables include factor usage, domestic and foreign sales, equity ownership positions by country of origin, price indices on inputs and outputs, four-digit industry classification, and the state in which the plant is located. Mexico contains 32 states and the plants are drawn from 129 four-digit (MEXSIC) industries. ${ }^{5}$ Since the focus of our empirical work is the relationship between spillovers and exports, we need to reliably measure the geographic concentration of economic activity in Mexico. To do so, we supplement the Secofi data with data from the 1986 and 1989 Mexico Industrial Census. The Census data include employment, number of establishments, and average wages by state and four-digit (ISIC) industry. ${ }^{6}$ Combining the data sets requires us to limit our study to the two years the Secofi sample overlaps with the Census, 1986 and 1989.

Table 1 shows total manufacturing employment in the Census and in the Secofi sample. The plants in the Secofi sample account for a substantial share of Mexican manufacturing activity; in 1989, they employed 29 percent of all manufacturing workers. The distinguishing feature of the plants in the Secofi sample is that they are considerably larger than the plants in the Census; in 1986, average workers per establishment is 321 in the Secofi sample, but only 67 in the Census. Table 2 shows the distribution of employment across two-digit (ISIC)

\footnotetext{
5 The Secofi data use an industrial classification code that is unique to Mexico. The code, which we call MEXSIC, is a close cousin of the SIC code.

6 The Mexico Industrial Census uses the United Nations Revision II ISIC code.
} 
industries in the Secofi sample and in the Census are nearly identical. Table 3 shows the distribution of employment across states in the Secofi sample and in the Census. The Secofi sample somewhat overestimates employment in the states that contain Mexico's largest cities (the Federal District, Mexico, and Nuevo León) and underestimates employment in border states (Baja California, Chihuahua, Sonora, and Tamaulipas). Two factors likely account for this fact. The Secofi sample, by design, targets medium and large plants, which happen to be located in Mexico's largest cities, and excludes in-bond foreign assembly plants, know as maquiladoras, which are concentrated in export processing zones located in border states.

In order to study the effect of the local concentration of export activity on the probability a plant exports, we need measures by industry of the geographic concentration of exports, MNE activity, and overall economic activity. We use the Census to estimate the geographic distribution of overall manufacturing activity in Mexico; this is appropriate as the Census is comprehensive. Since the Census does not contain information on export activity or on FDI, we use the Secofi sample to estimate the geographic distribution of exports and MNE activity in Mexico. To the extent medium and large plants account for most export activity in Mexico and to the extent that most MNEs are medium and large firms, the Secofi sample is a representative sample of plants that are likely to export and plants that are likely to be foreign owned. ${ }^{7}$ The data support this claim; the plants in the Secofi sample accounted for 43 percent

\footnotetext{
'More precisely, the Secofi sample is a representative sample of non-maquiladora plants that are likely to export or be foreign owned. The sample consciously excludes maquiladoras, which we regard as a virtue given the hypothesis we are testing. Maquiladoras have few linkages with the domestic economy; they import all inputs from parent firms abroad and export all output (until 1988, they were required to do so by law). Clearly, the export decision we posit does not characterize the decision made by maquiladoras. That decision is made by the foreign parent firm for whom the maquiladora is a branch plant. The absence of linkages between maquiladoras and local firms implies maquiladora exports should be excluded from a measure of local export activity.
} 
of Mexican manufacturing exports in 1986 and 45 percent in $1989 .{ }^{8}$

\section{B. Ownership and Export Behavior}

We define as MNEs plants with positive foreign equity ownership, even though the plants may not be majority foreign owned. Tables $4 a, 4 b$, and $4 c$ provide summary statistics for all plants, plants that export, and foreign-owned plants for 1986 and 1989 . The share of all plants that export over the two years was 27 percent. While there was an increase in the number of exporters between 1986 and 1989, the majority of firms that were exporting in 1989 were already doing in 1986. MNEs compose a considerable fraction of the sample; 28 percent of the plants had positive foreign equity ownership. Table $4 \mathrm{a}$ also shows the distribution of plants by region. ${ }^{2}$ There is a high degree of concentration in the center of the country and along the border; the Mexico City region contains 55 percent of the plants, the central states contain 21 percent, and the border states contain 17 percent.

On average, exporters employ more workers than do non-exporters. Foreign shipments average 16 percent of the total sales of exporters. The United States is the major foreign destination market; on average exporters send 56 percent of their foreign shipments to their northern neighbor. The geographic distribution of exporters, at least at the regional level, is similar to that for all plants. The fact that exporters are not overwhelmingly concentrated along

8 Maquiladoras account for most of the remaining manufacture exports.

9 We group states into five regions running north to south: the Border contains states that border the United States; the North contains the next tier of northern states; the Center contains states surrounding Mexico City; Mexico City contains the two states the capital occupies; and the South contains all states south of the capital. 
the border suggests that transport costs are not a dominant factor in the plant-location decision.

Not surprisingly, foreign-owned plants are more likely to export than are domesticallyowned plants; over the two years, 46 percent of foreign plants export. The United States is the most common source of foreign capital and Germany is the next most common. Of plants with foreign equity ownership, 60 percent have U.S. equity participation and 15 percent have German equity participation. Foreign-owned plants on average employ more workers than do domestically-owned plants and are more likely to be located in Mexico City.

\section{The Geography of Exports}

If there are localized externalities associated with exporting then we expect the plants that export in an industry to be geographically concentrated. The geographic concentration of export activity in Mexico is considerable, but this by itself is not evidence of spillovers. There are many factors that cause firms to agglomerate, such as regional variation in factor abundance and general spillovers. ${ }^{10}$ To isolate the effect of export spillovers on the probability a plant exports, we need control for the overall geographic concentration of industry activity. In this way, we hold constant geographic variation in resource abundance and other potential factors that contribute to industry agglomeration. Before turning to the empirical estimation we provide data on the geographic concentration of export activity in Mexico.

Localized export spillovers imply there will be an excess geographic concentration of export activity -- a geographic concentration of exporters beyond that which exists for plants in

10 The spatial allocation of factors is endogenous. For our purposes, it does not matter whether the general geographic concentration of factors is due to the exogenous characteristics of locations or to endogenous extemal economies. 
the industry as a whole. The simplest way to identify excess export concentration for a given industry is to compare the distribution of domestic sales across states with the distribution of exports across states. ${ }^{11}$ Consider a histogram of state-industry shares of national-industry domestic sales. If sales are highly geographically concentrated, there will be a large number of states whose share of national-industry sales is near zero and a few states whose share of national-industry sales is large. If, on the other hand, sales are evenly spread across states, the distribution of state-industry sales shares will be centered at approximately 3 percent $(1 / 32)$.

Let $s_{i j}$ be state $i$ 's share of domestic sales of three-digit (MEXSIC) industry $j$ and let $x_{i j}$ be state $i$ 's share of national exports of three-digit (MEXSIC) industry $j$. Both exports and sales data are from the Secofi sample. Figures $1 \mathrm{a}$ and $1 \mathrm{~b}$ show histograms for $s_{i j}$ using data from 1986 and $1989 .{ }^{12}$ For many industries a single state accounts for half or more of national industry sales. This, in combination with the fact that most state industries have a sales share near zero, is consistent with the idea that domestic sales are geographically concentrated. However, given that certain states are under-represented in the Secofi sample, there is little we can infer from the distribution of sales across state industries. What is informative is to compare Figures $1 \mathrm{a}$ and $1 \mathrm{~b}$ with similar figures for exports.

If exports are more geographically concentrated than sales, then compared to stateindustry sales shares, the distribution of state-industry shares of national industry exports will have a larger mass near zero and a larger mass with very high shares, but a lower mass at intermediate levels. Figures $2 \mathrm{a}$ and $2 \mathrm{~b}$ show histograms for $x_{i j}$, using data from 1986 and 1989 .

We use sales to mean shipments by plants from the point of production.

12 Figures $1 \mathrm{a}$ and $1 \mathrm{~b}$, and those that follow, pool three-digit industries together. We do so for purposes of presentation. The figures for individual industries are similar. 

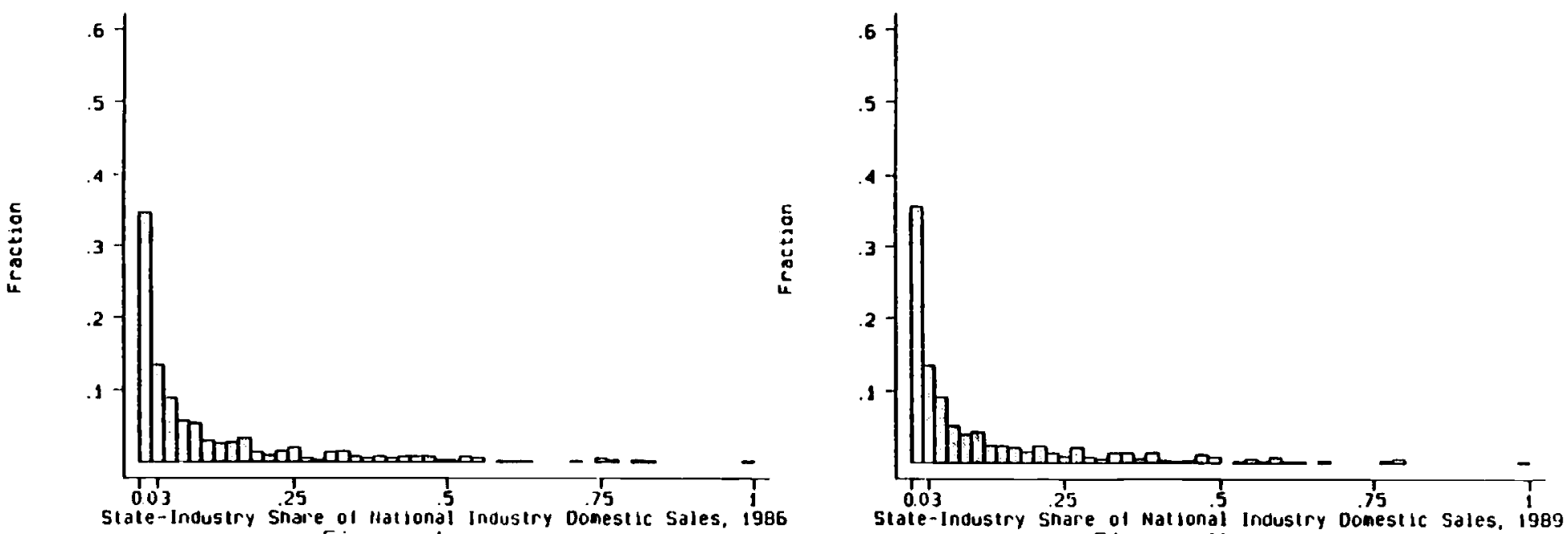

Figure la
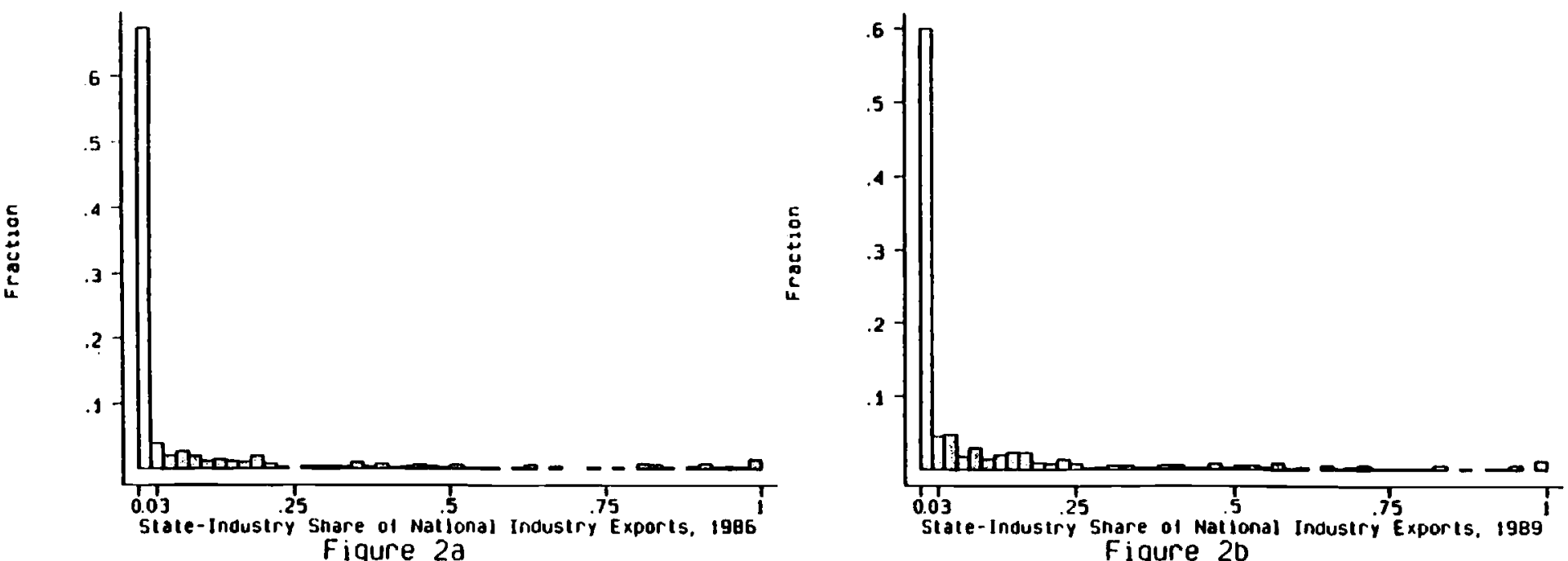

Figure 2b 
In 1989 , the fraction of state industries with export shares near zero is about 60 percent, while the fraction of state industries with sales shares near zero is only 35 percent. Also, the distribution of export shares has a smaller mass of state industries with shares between 5 percent and 25 percent, and a larger mass of state industries with very high shares, between 75 and 100 percent. This is consistent with the idea that exports are more geographically concentrated than sales. ${ }^{13}$

That exports are more concentrated than sales is, of course, not in and of itself evidence of spillovers. Transport-cost considerations give exporters different locational incentives from those of domestic producers. It would not be surprising to find, for instance, that the states that do all the exporting happen to have large ports or share a border with the United States. To identify the effects of export spillovers, it is necessary to control for other factors in the estimation, such as proximity to ports or borders, which affect the probability of exporting.

\section{Empirical Results}

In this section, we estimate the probability that a plant has positive exports. We present three main results which are robust across samples and specifications. Controlling for factor

13 A more formal way to present the data is to study the difference between a state-industry's share of nationalindustry exports and its share of national industry domestic sales. Define $e_{i j}$ such that

$$
x_{i j}-s_{i j}=e_{i j}
$$

By definition, $\Sigma_{i} s_{i j}=1$ and $\Sigma_{i} x_{i j}=1$, which implies $\Sigma_{i} e_{i j}=0$. A lack of excess export concentration would imply that the $e_{i j}$ 's are symmetrically distributed around 0 , while the existence of excess export concentration would imply the distribution of the $e_{i j}$ 's are skewed right. That is, excess concentration means that for a given industry most states have an $e_{i j}$ that is negative but small in absolute value and that one or two states have an $e_{i j}$ that is positive and large in absolute value. The skewed distribution of the $e_{i j}$ 's will be centered near zero, but with a larger mass to the left of zero than to the right (i.e., the median will be less than the mean). We find that in both 1986 and 1989 the distribution of $x_{i j}-s_{i j}$ is skewed right; the skewness statistic is 1.30 for 1986 and 1.32 for 1989, compared to a skewness statistic of 0 for a symmetric distribution. The asymmetry of the distribution is consistent with excess export concentration. Using a skewness/kurtosis test we reject the null hypothesis that $x_{i j}-s_{i j}$ is normally distributed at any level of significance. 
costs, output prices, and other variables which affect the export decision, we find that (1) MNEs are roughly twice as likely as domestic plants to export, (2) for a given location, a higher concentration of MNE export activity significantly raises the probability that a plant exports, and (3) a higher concentration of export activity in general has no effect on plant export behavior.

\section{A. Model Specification}

Equation (11) describes the decision to export as a function of domestic and foreign output prices, factor prices, and geographic concentration measures. Table A.1 in the appendix defines the regressors.

We measure geographic concentration at the level of the state and three-digit industry. To control for variation in the size of industries at the national level, we measure the geographic concentration of industry as the state-industry share of national industry activity. Naturally, we want to control for situations where the state-industry is large purely because the state is large. To do so, we normalize by the state share of national manufacturing activity. The resulting measure of geographic concentration is the ratio,

\section{State-industry share of national industry activity}

State share of national manufacturing activity

This measure is similar to those used in recent empirical literature on economic geography (e.g., Glaeser et al. 1992, Henderson 1994).

The three geographic activity measures of interest are those for the overall concentration of economic activity, the concentration of export activity, and the concentration of MNE export activity. We define overall industry concentration as the state-industry share of national industry 
employment, relative to the state share of national manufacturing employment. ${ }^{14}$ We use this measure to control for the effects of general spillovers and exogenous site-specific factors of production, which allows us to identify the effects of different types of export spillovers.

We define local export concentration as the state-industry share of national industry exports, relative to the state share of national manufacturing exports. ${ }^{15}$ This measure controls for situations where a state industry has high exports purely because the state has high exports, such as might be the case in border states or states with port facilities. For a state industry to show a high level of export concentration, the state must be relatively specialized in exporting the product of that industry. If export spillovers exist, we expect the probability a plant has positive exports to be increasing in the level of local export concentration.

We measure MNE export activity as the share of state-industry MNE exports in national industry exports, relative to the state share of national manufacturing exports. Our measure of local export concentration encompasses MNE exports. By including an independent measure MNE export activity, we allow for the possibility that MNEs, rather than domestic exporters, are the source of spillovers. If MNEs generate spillovers for local exporters, we expect the probability a plant exports to be increasing in the local concentration of MNE export activity. Other explanatory variables follow the specification in expression (11). We measure

${ }_{14}$ As mentioned in section III, we calculate overall industry concentration with data from the Industrial Census and export concentration and MNE export activity with data from the Secofi sample. We measure overall industry concentration at the three-digit ISIC level and export concentration and MNE export activity at the three-digit MEXSIC level. The latter is more disaggregated than the former, as the sample contains 27 three-digit ISIC industries and 54 three-digit MEXSIC industries. Although the Census data is at the four-digit ISIC level, we are required to use data at the three-digit level in order to combine the Census with the Secofi sample.

${ }^{15}$ We measure local export concentration and MNE export activity excluding the plant on which the observation is taken. 
domestic prices using four-digit producer-price indices, deflated by the wholesale-price index. ${ }^{16}$ We measure non-labor factor costs using four-digit input-price indices for construction, machinery, transportation, office equipment, raw materials, and electricity. We measure labor costs as average remuneration per worker by state and three-digit industry. We include as regressors average tariffs and import-license requirements by four-digit industry. In addition to its effects on the output price, trade policy affects export behavior through its effects on input prices. As additional control variables we include dummy variables for the foreign-ownership status of the plant, a dummy variable for whether the plant subcontracts for other plants, employment in the plant relative to industry average employment, value-added tax payments as a share of sales, royalty payments as a share of sales, distance from a plant's state capital to the Mexico-U.S. border and to Mexico City, and dummy variables for industry, region, and year.

\section{B. Estimation Results}

Tables 5 and 6 report maximum likelihood coefficient estimates for a logit specification of the model described in expression (11). We estimate the regression over several samples, using both current and lagged values of geographic concentration measures. We direct the discussion towards the results on export spillovers and MNE export spillovers. Given the model we estimate is a reduced form, the results on input prices and trade protection variables are difficult to interpret. From section II, these variables likely affect production for both domestic and foreign markets. Hence, we cannot identify the parameters that are specific to foreign

16 The specification in expression (11) calls for the inclusion of export prices as an independent variable. Unfortunately, no data for export prices exist. It is possible to construct unit values for exports (defined as sales divided by quantities of exports), but unit values do not offer an economically meaningful measure of export prices since they are not comparable to domestic prices. 
production and distribution costs.

Column (1) in Table 5 gives results for the full sample. The coefficients on local export concentration and MNE export activity are positive and statistically significant, indicating that an increase in the level of these variables raises the probability that a plant exports. ${ }^{17}$ This result is consistent with the idea that there are positive localized spillovers associated with exporting. Plants with foreign equity participation are also more likely to export, with the effect depending on the country of origin. The results suggest that plants with Japanese or North American foreign equity participation are more likely to export than are domestic plants, while plants with European ownership are not.

Other variables that are statistically significant are relative plant size, the state-industry wage, and royalty payments as a share of sales. For a given industry, an increase in plant size increases the probability a plant exports. This is consistent with declining per unit foreign distribution costs, in which case larger plants are able to spread the fixed costs of penetrating foreign markets over more production. An increase in the average wage in a given region is associated with a higher probability of exporting. This is consistent with export production being relatively skill-intensive, where high wages reflect high levels of location or individualspecific human capital. Higher royalty payments are also associated with a higher export probability, which may reflect the use of more sophisticated production technologies or more product differentiation in plants that export.

To check the robustness of the findings, we re-estimate the model on several restricted samples. Column (2) shows results where we exclude foreign plants from the sample.

\footnotetext{
17 The threshold level of statistical significance we adopt is 5 percent.
} 
Excluding foreign plants controls for the possibility that the results are merely the byproduct of the fact that foreign plants are more likely to export and that they are also more likely to be located together. The results are similar to those in column (1). In particular, local export concentration and MNE export activity are again positive and statistically significant.

Columns (3) and (4) shows results where we restrict the set of industries included in the sample. Our concern is that the measure of overall industry concentration may not adequately control for unobserved site-specific characteristics, in which case our results on export concentration and MNE export activity may be merely capturing the fact that exporters locate in regions whose natural endowments make exporting more feasible. Our measure of overall industry concentration is at the three-digit ISIC level (see note 14), which groups together industries whose subindustries have highly dissimilar factor intensities. One example is worth noting. Nearly all exports of seafood packing in our sample come from two states, Baja California and Tamaulipas. Both are coastal states and home to Mexico's largest shrimping fleets; hence, it is not surprising that most shrimp-packing plants are located in these states. Shrimp packing is a four-digit industry within the three-digit industry of food products. Since our measure of overall industry concentration is at the three-digit level, it may fail to control for the fact that these two states have large concentrations of shrimp packers.

We exclude two types of industries: those that are relatively intensive in the use of natural resources, such as food products, petroleum refining, and tequila, and those which have relatively high transport costs and hence tend to produce for the local market, such as cement, 
bread, and tortillas. ${ }^{18}$ These are industries in which site-specific factors are likely to be relatively important in the export decision. Columns (3) and (4) show that while the signs, magnitudes, and patterns of significance on MNE export activity and foreign ownership are similar to those in the first two columns, local export concentration is now statistically insignificant in both regressions. Coefficient estimates for other variables are largely unaffected.

The weakness of the results on local export concentration is itself a striking result. Rarely are empirical studies of spillovers able to distinguish between different types of geographic concentration. The fact that local export concentration is so sensitive to the set of industries that are included suggests caution in inferring the existence of spillovers, without first adequately controlling for exogenous site-specific characteristics.

The results on the geographic concentration measures describe the spillovers associated with exporting. Plants benefit from the specific activities of MNEs, and not from export activity in general. What makes MNEs distinct is that they have foreign parent firms. This may imply that MNEs are a better source of information about foreign markets than are domestic exporters. A second possibility is that MNEs attract specialized input suppliers to their locations, and that these suppliers in turn attract producers who desire to export. This latter channel has been formalized by Rivera-Batiz and Rivera-Batiz (1991) and is consistent with Head and Ries' (1994) finding that foreign firms locating in China are attracted to cities with relatively large

18 The excluded industries and their MEXSIC classification codes are the following: fruit and vegetable products $(2011,2012)$, wheat and corn milling $(2022,2023)$, coffee and tea $(2025,2026,2027)$, sugar $(2031)$, meat products $(2041,2049)$, milk products $(2051,2052,2053,2054,2059)$, seafood packing (2060), bread (2071), tortillas (2093), animal feed (2098), fermented cactus (2115), tobacco products $(2201,2202,2209)$, cotton packing (2311), lumber (2611), petroleum refining (3111), bricks and clay (3331, 3332), cement (3341), rail manufacturing (3820), shipbuilding (3831), and aircraft manufacturing (3832). Excluding these industries reduces the sample size by 386 observations (193 establishments). 
concentrations of input suppliers.

Finally, to control for simultaneity bias in the geographic concentration measures, we reestimate the model using lagged values for the concentration measures. This limits us to using observations from one year, 1989. The lagged values we use are those from 1986 . Table 6 reports the results, which use the same sample restrictions as the regressions in Table 5 . We observe the same basic pattern of results. MNE export activity is positive and significant in all regressions; local export concentration is significant only when natural-resource and transportcost intensive industries are included in the sample. One change from the previous results is that Japanese foreign ownership is no longer associated with a higher probability of exporting.

We experimented with several other alternative specifications, which are not reported in the paper. We first experimented with alternative definitions of the geographic and export concentration measures, using numbers of plants as a measure of activity instead of employment or export volumes. To test whether all the effects of foreign investment are due to a clustering of foreign firms around Mexico City and the border regions, we redid the estimation excluding those two regions. We also redid the estimation excluding major outliers, defined as foreign investment shares greater than two standard deviations from the mean. None of these alternative specifications affected the results. Finally, we added export prices to the basic specification. Although the model suggests the inclusion of both domestic and export prices, the analysis above proxies for export prices using industry dummies, since export price data is quite poor. Unit values, calculated at the four-digit level, were used for export prices, although the problems associated with these measures of price are well known. In addition, it was only possible to calculate unit values for a fraction of the total sample, leading to selection problems. Despite 
these drawbacks, the resulting estimates again did not affect the original results. In general, the coefficient on the export price was statistically insignificant.

\section{Fixed-Effects Estimation}

The results presented in Tables 5 and 6 do not fully control for idiosyncratic factors that affect the export decision. If plants differ by an unobserved individual effect, then the coefficient estimates will be biased. We adopt Chamberlain's (1980) approach for fixed-effects logit estimation, which involves first-differencing the data. With first-differenced data in a logit framework, the only plants whose observations add information to the likelihood function are those that make a transition between activity states over time. In the case we study, of an export decision made in two periods, those are plants which between 1986 and 1989 either go from not exporting to exporting $(0,1)$ or from exporting to not exporting $(1,0)$. Unfortunately, for our purposes, there are only 250 such plants in our sample, which is 12 percent of the total number of plants. When we impose restrictions, by excluding natural-resource industries or foreign plants, this reduces the sample size further still.

Table 7 reports results from fixed-effects logit estimation of expression (11). Given the small sample size, it is not surprising that most of the coefficients are now statistically insignificant. The only variable which remains significant is MNE export activity. The coefficient is positive in all four regressions and statistically significant in the two regressions that restrict the sample to domestic plants. Our finding on the effects of MNE export activity, then, appears to robust across samples and across specifications. The fact that local export concentration is significant in no fixed-effect regression casts further doubt on the existence of 
general export spillovers.

\section{Interpreting the Parameter Estimates}

The nonlinearity of the logit specification makes the economic significance of the coefficients reported in Tables 5 and 6 difficult to interpret. In Table 8, we compute the partial effects of several independent variables on the probability of exporting. To do so, we first solve the predicted probability a plant exports based on the estimated coefficients and the sample means of the independent variables. To give a sense of how a particular variable affects the probability of exporting, we calculate the change in this probability due to a one standard deviation increase in the regressor, holding all other variables constant at their mean levels.

For coefficient estimates from column (3) of Table 5, MNE export activity has a substantial impact on the probability that a firm exports; an increase in MNE export activity of one standard deviation raises the "average" plant's export probability from .22 to .26 . The increase is about the same for coefficient estimates from the regressions that exclude foreign plants (column (4) of Table 5). All else equal, plants with U.S. equity participation are 17 percent more likely to export than are domestic plants, and plants with Japanese equity participation are 30 percent more likely to export than are domestic plants. An increase in local wages and an increase in plant size of one standard deviation increases the plant's probability of exporting by 3.8 percent and 10.4 percent respsectively. An increase in royalty payments by one standard deviation increases the probability of exporting by three percentage points.

\section{Concluding Remarks}


Anecdotal evidence suggests that the process of breaking into foreign markets can be very difficult. Potential exporters must obtain information about foreign tastes and establish distribution channels in foreign markets. One obvious way for firms to learn about export markets is to observe other exporters who have already acquired experience selling abroad. Those exporters may be other domestic firms, or multinationals.

In this paper, we test for the possibility that other exporters can reduce the cost of foreign market access for a firm contemplating the jump into export markets. In particular, we test whether locating near other exporters increases the probability of exporting. The basis for the study is 2,113 Mexican manufacturing plants over the period between 1986 and 1990 . Following Mexico's trade reform in 1985, many Mexican manufacturers turned away from the previously protected domestic market towards outside markets. These changes during the 1980s allow us to identify the kinds of firms most likely to become exporters.

Ours is the first study which provides statistical evidence on the role of foreign firms as "catalysts" for other exporters. Using a logit specification, we find that locating near a multinational exporter significantly raises the probability of exporting for an individual firm. These results are robust to the inclusion of other measures such as overall industrial activity in a region, proximity to the capital city and border regions, and other factors. Yet increased activity by domestic exporters has no impact on export probabilities. Why are export spillovers restricted to multinational activity? Foreign-owned enterprises are a natural conduit for information about foreign markets and technology, and a natural channel through which domestic firms can distribute their goods. To the extent that foreign investors directly or indirectly provide information and distribution services, their activities enhance the export prospects of 
local firms.

One implication is that firms wishing to break into export markets should locate in areas with a concentration of multinational export activity. Another implication is that governments may wish to encourage exporters or potential exporters to locate near each other. One policy option adopted by governments is the development of export processing zones (EPZs), special economic zones reserved for exporting firms. These zones often confer special benefits to exporters, such as duty-free imported inputs, tax holidays, or subsidized infrastructure. Our research suggests that by forcing potential exporters to locate near each other, EPZs could in in principle help reduce the costs of breaking into foreign markets. In practice, however, EPZs have often been located in regions which are removed from domestic production centers. This has led to isolating would-be exporters from multinationals and other exporting firms. 
Appendix: Table A.1 Variable Definitions

Variable

Export

Overall Industry

Concentration ${ }^{\mathrm{a}}$

Local Export

Concentration $^{\mathrm{b}, \mathrm{e}}$

MNE Export

Activity ${ }^{\text {b.c }}$

Plant FDI

Domestic Price $^{\mathrm{d}, e}$

Region Wage $e^{a, d}$

Plant Size

Royalty Payments

Proximity USA

Proximity Mexico City

Maquila Dummy

Value Added Taxes

Output tariff

Input tariffe

Output quota

Input quota ${ }^{e}$

Input prices ${ }^{\mathrm{d}, e}$
Definition

Equals one if plants has positive exports.

State industry share of national industry employment/

State share of national manufacturing employment

State-industry share of national industry exports/

State share of national manufacturing exports

(State-industry MNE exports/national industry exports)/

State share of national manufacturing exports

Equals one if plant has positive foreign equity participation (Plant FDI: USA, Plant FDI: Japan etc. equal one if plant has positive foreign equity from indicated country).

Four-digit producer price index.

Average remunerations per worker in state industry.

Employment in plant/Industry average plant employment.

Royalties paid/Sales.

Distance in kilometers to nearest major U.S. border crossing.

Distance in kilometers to Mexico City.

Equals one if plant has positive income from subcontracting.

Value-added tax payments/Sales.

Average tariff (\%) on outputs by four-digit industry.

Average tariff (\%) on inputs by four-digit industry.

Average share of outputs subject to import-license requirement by four-digit industry.

Average share of inputs subject to import-license requirement by four-digit industry.

Four-digit price indices for construction, machinery, transportation, office equipment, raw materials, electricity.

' Industry is three-digit ISIC classification (indicates data from Industrial Census; all other data from Secofi sample).

${ }^{b}$ Industry refers to three-digit MEXSIC classification.

c Calculated excluding the plant on which the observation is taken.

${ }^{d}$ Deflated by wholesale price index.

' Industry refers to four-digit MEXSIC classification. 


\section{References}

Aitken, B. and A.E. Harrison. 1992. "Does Proximity to Foreign Firms Induce Technology Spillovers?" Mimeo, World Bank and International Monetary Fund.

Blomstrom, M. 1986. "Foreign Investment and Productive Efficiency: The Case of Mexico." Journal of Industrial Economics. 25:

Blomstrom, M. and H. Persson. 1983. "Foreign Investment and Spillover Efficiency in an Underdeveloped Economy: Evidence from Mexican Manufacturing Industry." World Development 11:

Blomstrom, M. and E.W. Wolff. 1989. "Multinational Corporations and Productivity Convergence in Mexico." Mimeo, New York University.

Carlton, D.W. 1983. "The Location and Employment Choices of New Firms: An Econometric Model with Discrete and Continuous Endogenous Variables." Review of Economics and Statistics 65: 440-449.

Caves, R.E. 1974. "Multinational Firms, Competition, and Productivity in Host-Country Markets." Economica.

Chamberlain, G. 1980. "Analysis of Covariance with Qualitative Data." Review of Economics and Statistics 47: 225-238.

Davies, H. 1977. "Technological Transfer through Commercial Transactions." Journal of Industrial Economics. 26: 165-171.

Glaeser, E., H. Kallal, J. Sheinkman, and A. Shleifer. 1992. "Growth in Cities." Journal of Political Economy 100: 1126-1152.

Gonclaves, R. 1986. "Technological Spillovers and Manpower Training: A Comparative Analysis of Multinational and National Enterprises in Brazilian Manufacturing." Journal of Development Economics. 11:

Haddad, M. and A.E. Harrison. 1993. "Are There Positive Spillovers from Direct Foreign Investment? Evidence from Panel Data for Morocco." Journal of Development Economics, October.

Head, K. and J. Ries. 1994. "Inter-City Competition for Foreign Investment: Static and Dynamic Effects of China's Incentive Areas." Mimeo, University of British Columbia.

Head, K., J Ries, and D. Swenson. 1994. "Agglomeration Benefits and Location Choice: Evidence from Japanese Manufacturing Investments." Mimeo, University of British Columbia 
and University of California.

Henderson, J.V. 1986. "Efficiency of Resource Usage and City Size." Journal of Urban Economics 19: 47-70.

Henderson, J.V. 1994. "Externalities and Industrial Development." NBER Working Paper No. 4730 .

Instituto Nacional de Estadística, Geographía e Informática (INEGI). XII Censo Industrial, (1985). Mexico City: INEGI. Resultados Oportunos, (1989), Aguascalientes: INEGI.

Jaffe, A., M. Trajtenberg, and R. Henderson. 1993. "Geographic Localization of Knowledge Spillovers as Evidenced by Patent Citations." Quarterly Journal of Economics 108: 577-598.

Kessing, D.B. 1983. "Linking Up to Distant Markets: South to North Exports of Manufactured Consumer Goods." American Economic Review 73: 338-342.

Morawetz, D. 1981. Why the Emperor's New Clothes are not Made in Colombia. London: University of Oxford Press.

Nakamura, R. 1985. "Agglomeration Economies in Urban Manufacturing Industries: A Case of Japanese Cities." Journal of Urban Economics 17: 108-124.

Rhee, Y.W. and T. Belot. 1990. "Export Catalysts in Low-Income Countries." World Bank Discussion Papers No. 72.

Rivera-Batiz, F.L. and L.A. Rivera-Batiz. 1991. "The Effects of Direct Foreign Investment in the Presence of Increasing Returns due to Specialization." Journal of Development Economics 34: $287-307$.

Roberts, M. and J. Tybout. 1993. "An Empirical Model of Sunk Costs and the Decision to Export." Mimeo, Pennsylvania State University and Georgetown University.

Teece, D.J. 1977. "Technology Transfer by Multinational Firms: The Resource Cost of Transferring Technological Knowhow." Economic Journal. 87: 242-261.

Wheeler, D. and A. Mody. 1992. "International Investment Location Decisions." Journal of International Economics. 33: 57-76. 
Table 1: Total Employment, Census Data vs. Sample Data

$\begin{array}{lcc} & \frac{1986}{2,529,121} & \frac{1989}{2,472,826} \\ \text { Census } & 682,336 & 702,786\end{array}$

Table 2: Industry Employment Shares 1986, Census Data vs. Sample Data

\begin{tabular}{|c|c|c|c|c|c|}
\hline & Census & Census & Sample & Sample & Sample \\
\hline ISIC & No. of & Employ. & No. of & Employ. & Export \\
\hline Code & Estab. & Share & Estab. & Share & Share \\
\hline 31 & 46866 & 2005 & 395 & .2036 & .0430 \\
\hline 32 & 15794 & .1531 & 305 & .1374 & .0133 \\
\hline 33 & 15275 & .0485 & 67 & .0153 & .0015 \\
\hline 34 & 6793 & .0507 & 167 & .0547 & .0055 \\
\hline 35 & 4688 & .1582 & 480 & .1812 & .1634 \\
\hline 36 & 9320 & .0543 & 149 & .0662 & .0537 \\
\hline 37 & 1015 & .0473 & 62 & .0459 & .1053 \\
\hline 38 & 28417 & .2778 & 474 & .2894 & .6056 \\
\hline 39 & 1237 & .0097 & 27 & .0065 & .0088 \\
\hline
\end{tabular}


Table 3: State Employment Shares for 1986, Census Data vs. Secofi Sample Data

State

Aguascalientes

Baja California ${ }^{b}$

Baja California Sur

Campeche

Chihuahua $^{b}$

Chiapas

Coahuilab

Colima

Federal District ${ }^{c}$

Durango

Guerrero

Guanajuato

Hidalgo

Jalisco $^{c}$

Michoacan

Mexico $^{c}$

Morelos

Nayarit

Nuevo Leon ${ }^{\mathrm{b}, \mathrm{c}}$

Oaxaca

Puebla

Quintana Roo

Queretero

Sinaloa

San Luis Potosi

Sonora ${ }^{b}$

Tabasco

Tlaxcala

Tamaulipas ${ }^{b}$

Veracruz

Yucatan

Zacatecas
Sample Employment Share

.0076

.0091

.0005

.0008

.0112

.0003

.0452

.0002

.2775

.0067

.0038

.0261

.0184

.0763

.0062

.2189

.0145

.0010

.1246

.0042

.0489

.0005

.0182

.0063

.0142

.0080

.0046

.0103

.0073

.0173

.0147

.0013
Census Employment Share

.0114

.0223

.0117

.0023

.0483

.0058

.0354

.0017

.2126

.0144

.0046

.0423

.0185

.0853

.0184

.1557

.0102

.0033

.0781

.0088

.0428

.0019

.0188

.0124

.0176

.0204

.0000

.0105

.0274

.0481

.0115

.0029

${ }^{b}$ Border state. ' State contains one of Mexico's three largest cities. 
Variable definitions for Table 4 (for other definitions see Table A.1):

Export

Export Share

Export USA

\% Export USA

Plant FDI

Local FDI

Border

North

Central

Mexico City

South
Equals one if plant has positive exports.

Exports/Total sales.

Equals one if plant exports to US ( $\mathrm{Can}=$ Canada, etc).

$\%$ of exports to US (Can = Canada, etc).

Equals one if plant has positive foreign equity.

Number of foreign plants in plant's state industry.

Equals one if plant located in Border state.

Equals one if plant located in Northern state.

Equals one if plant located in Central state.

Equals one if plant located in Mexico City Region.

Equals one if plant located in Southern state.

Table 4a: Summary Statistics for All Plants, 1986 and 1989

\begin{tabular}{llccc} 
Variable & & Obs & Mean & Std. Dev. \\
\cline { 3 - 5 } Employment & & 4226 & 323.6131 & 328.6391 \\
Export & & 4226 & 0.2714 & 0.4447 \\
Plant FDI & & 4226 & 0.2778 & 0.4480 \\
FDI Local & & 4226 & 4.4321 & 6.0949 \\
Border & 4226 & 0.1691 & 0.3750 \\
North & 4226 & 0.0372 & 0.1892 \\
Central & 4226 & 0.2052 & 0.4039 \\
Mexico City & 4226 & 0.5561 & 0.4970 \\
South & 4226 & 0.0329 & 0.1784
\end{tabular}

Table 4b: Summary Statistics for Exporters, 1986 and 1989

\begin{tabular}{lccc} 
Variable & Obs & Mean & Std. Dev. \\
\cline { 2 - 4 } Employment & 1147 & 442.2658 & 427.5323 \\
Export Share & 1147 & 0.1515 & 0.2083 \\
Export USA & 1147 & 0.7350 & 0.4416 \\
Export Canada & 1147 & 0.1099 & 0.3128 \\
Export Other & 1147 & 0.5946 & 0.4912 \\
\% Export USA & 1147 & 57.5144 & 44.5186 \\
\% Export Canada & 1147 & 2.1064 & 10.5408 \\
\% Export Other & 1147 & 40.1177 & 44.4023 \\
Plant FDI & 1147 & 0.4682 & 0.4992 \\
FDI Local & 1147 & 5.5955 & 8.2068 \\
Border & 1147 & 0.1936 & 0.3953 \\
North & 1147 & 0.0349 & 0.1835 \\
Central & 1147 & 0.2171 & 0.4124 \\
Mexico City & 1147 & 0.5301 & 0.4993 \\
South & 1147 & 0.0244 & 0.1544
\end{tabular}


Table 4c: Summary Statistics for Foreign-Owned Plants, 1986 and 1989

\begin{tabular}{lccc} 
Variable & Obs & Mean & Std. Dev \\
\cline { 2 - 4 } Employment & 1174 & 395.9100 & 416.6546 \\
Export & 1174 & 0.4574 & 0.4984 \\
FDI Local & 1174 & 6.7964 & 8.1363 \\
Plant FDI: USA 1174 & 0.5971 & 0.4907 & \\
Plant FDI: Canada & 1174 & 0.0443 & 0.2058 \\
Plant FDI: Japan & 1174 & 0.0349 & 0.1837 \\
Plant FDI: Germany & 1174 & 0.1457 & 0.3529 \\
Plant FDI: Spain & 1174 & 0.0596 & 0.2369 \\
Plant FDI: Other & 1174 & 0.3084 & 0.4620 \\
Border & 1174 & 0.1465 & 0.3538 \\
North & 1174 & 0.0222 & 0.1472 \\
Central & 1174 & 0.1772 & 0.3820 \\
Mexico City & 1174 & 0.6303 & 0.4829 \\
South & 1174 & 0.0239 & 0.1527
\end{tabular}




\begin{tabular}{|c|c|c|c|c|}
\hline \multicolumn{5}{|c|}{$\begin{array}{l}\text { Table 5: Logit Specification for Decision to Export } \\
\text { (asymptotic t-statistics in parentheses) }\end{array}$} \\
\hline & \multicolumn{2}{|c|}{ All Industries } & \multicolumn{2}{|c|}{ Excluding Natural Resources } \\
\hline & $\begin{array}{r}\text { All Plants } \\
\text { (1) }\end{array}$ & $\begin{array}{r}\text { Domestic } \\
\text { Only (2) }\end{array}$ & $\begin{array}{r}\text { All Plants } \\
(3)\end{array}$ & $\begin{array}{r}\text { Domestic } \\
\text { Only (4) } \\
\end{array}$ \\
\hline $\begin{array}{l}\text { Overall Industry } \\
\text { Concentration }\end{array}$ & $\begin{array}{r}-.03554 \\
(-0.777)\end{array}$ & $\begin{array}{l}-.04022 \\
(-0.698)\end{array}$ & $\begin{array}{r}-.06617 \\
(-1.347)\end{array}$ & $\begin{array}{r}-.10485 \\
(-1.615)\end{array}$ \\
\hline $\begin{array}{l}\text { Local Export } \\
\text { Concentration }\end{array}$ & $\begin{array}{l}.00839 \\
(3.394)\end{array}$ & $\begin{array}{l}.00750 \\
(3.146)\end{array}$ & $\begin{array}{l}.00368 \\
(0.607)\end{array}$ & $\begin{array}{l}.00170 \\
(0.255)\end{array}$ \\
\hline $\begin{array}{r}\text { MNE Export } \\
\text { Activity }\end{array}$ & $\begin{array}{l}.04011 \\
(3.270)\end{array}$ & $\begin{array}{l}.06607 \\
(3.648)\end{array}$ & $\begin{array}{l}.03704 \\
(2.634)\end{array}$ & $\begin{array}{l}.09963 \\
(3.214)\end{array}$ \\
\hline Plant FDI: USA & $\begin{array}{l}.81165 \\
(8.190)\end{array}$ & & $\begin{array}{r}.87814 \\
(8.562)\end{array}$ & \\
\hline Plant FDI: Europe & $\begin{array}{r}.28918 \\
(1.700)\end{array}$ & & $\begin{array}{r}.30883 \\
(1.742)\end{array}$ & \\
\hline Plant FDI: Japan & $\begin{array}{r}.98269 \\
(2.559)\end{array}$ & & $\begin{array}{l}1.3638 \\
(3.323)\end{array}$ & \\
\hline Plant FDI: Other & $\begin{array}{r}.63647 \\
(4.685)\end{array}$ & & $\begin{array}{r}.67242 \\
(4.675)\end{array}$ & \\
\hline Domestic Price & $\begin{array}{r}.4786 \\
(2.545)\end{array}$ & $\begin{array}{r}.05527 \\
(0.234)\end{array}$ & $\begin{array}{r}.42369 \\
(2.160)\end{array}$ & $\begin{array}{r}.01441 \\
(0.057)\end{array}$ \\
\hline $\begin{array}{r}\text { Tariffs on Output } \\
\text { (TR1) }\end{array}$ & $\begin{array}{r}-.01675 \\
(-2.073)\end{array}$ & $\begin{array}{r}-.01938 \\
(-1.882)\end{array}$ & $\begin{array}{r}-.02342 \\
(-2.605)\end{array}$ & $\begin{array}{r}-.02364 \\
(-2.006)\end{array}$ \\
\hline $\begin{array}{r}\text { Quotas on Output } \\
\text { (TR2) }\end{array}$ & $\begin{array}{r}.01272 \\
(3.026)\end{array}$ & $\begin{array}{r}.00849 \\
(1.499)\end{array}$ & $\begin{array}{r}.01027 \\
(2.192)\end{array}$ & $\begin{array}{r}.00973 \\
(1.565)\end{array}$ \\
\hline $\begin{array}{r}\text { Tariffs on Inputs } \\
\text { (TR3) }\end{array}$ & $\begin{array}{r}.02713 \\
(1.648)\end{array}$ & $\begin{array}{r}.01265 \\
(0.621)\end{array}$ & $\begin{array}{l}.02732 \\
(1.516)\end{array}$ & $\begin{array}{l}.02205 \\
(0.966)\end{array}$ \\
\hline $\begin{array}{r}\text { Quotas on Inputs } \\
\text { (TR4) }\end{array}$ & $\begin{array}{l}-.02305 \\
(-4.131)\end{array}$ & $\begin{array}{l}-.02458 \\
(-3.743)\end{array}$ & $\begin{array}{l}-.03788 \\
(-4.972)\end{array}$ & $\begin{array}{r}-.04416 \\
(-4.749)\end{array}$ \\
\hline $\mathrm{TR} 1{ }^{*} \mathrm{TR} 2$ & $\begin{array}{l}-.00039 \\
(-3.094)\end{array}$ & $\begin{array}{l}-.00023 \\
(-1.395)\end{array}$ & $\begin{array}{l}-.00033 \\
(-2.355)\end{array}$ & $\begin{array}{r}-.00023 \\
(-1.318)\end{array}$ \\
\hline TR3*TR4 & $\begin{array}{r}.00121 \\
(4.029)\end{array}$ & $\begin{array}{l}.00124 \\
(3.524)\end{array}$ & $\begin{array}{l}.00151 \\
(4.159)\end{array}$ & $\begin{array}{l}.00156 \\
(3.692)\end{array}$ \\
\hline $\begin{array}{r}\text { Construction Price } \\
\text { Index }\end{array}$ & $\begin{array}{l}-5.9354 \\
(-1.229)\end{array}$ & $\begin{array}{r}.30812 \\
(0.043)\end{array}$ & $\begin{array}{l}-5.5103 \\
(-1.104)\end{array}$ & $\begin{array}{r}2.5154 \\
(0.338)\end{array}$ \\
\hline
\end{tabular}




\begin{tabular}{|c|c|c|c|c|}
\hline & \multicolumn{2}{|c|}{ All Industries } & \multicolumn{2}{|c|}{ Excluding Natural Resources } \\
\hline & $\begin{array}{r}\text { All Plants } \\
\text { (1) }\end{array}$ & $\begin{array}{r}\text { Domestic } \\
\text { Only (2) }\end{array}$ & $\begin{array}{r}\text { All Plants } \\
\text { (3) }\end{array}$ & $\begin{array}{r}\text { Domestic } \\
\text { Only (4) }\end{array}$ \\
\hline $\begin{array}{r}\text { Machinery Price } \\
\text { Index }\end{array}$ & $\begin{array}{l}-.91908 \\
(-2.203)\end{array}$ & $\begin{array}{l}-1.0762 \\
(-2.005)\end{array}$ & $\begin{array}{l}-.78473 \\
(-1.696)\end{array}$ & $\begin{array}{l}-.66577 \\
(-1.065)\end{array}$ \\
\hline $\begin{array}{r}\text { Transportation Price } \\
\text { Index }\end{array}$ & $\begin{array}{l}-.77931 \\
(-1.550)\end{array}$ & $\begin{array}{l}-.34392 \\
(-0.572)\end{array}$ & $\begin{array}{l}-.65994 \\
(-1.187)\end{array}$ & $\begin{array}{l}-.36141 \\
(-0.533)\end{array}$ \\
\hline $\begin{array}{l}\text { Office Equipment } \\
\text { Price Index }\end{array}$ & $\begin{array}{l}-5.9434 \\
(-5.876)\end{array}$ & $\begin{array}{l}-6.4572 \\
(-5.238)\end{array}$ & $\begin{array}{l}-5.1698 \\
(-4.431)\end{array}$ & $\begin{array}{l}-5.2816 \\
(-3.670)\end{array}$ \\
\hline $\begin{array}{r}\text { Raw Material Price } \\
\text { Index }\end{array}$ & $\begin{array}{l}.18315 \\
(0.883)\end{array}$ & $\begin{array}{l}.36829 \\
(1.337)\end{array}$ & $\begin{array}{l}-.23698 \\
(-1.059)\end{array}$ & $\begin{array}{l}-.26704 \\
(-0.821)\end{array}$ \\
\hline $\begin{array}{r}\text { Electricity Price } \\
\text { Index }\end{array}$ & $\begin{array}{r}4.78857 \\
(1.890)\end{array}$ & $\begin{array}{r}1.38437 \\
(0.374)\end{array}$ & $\begin{array}{l}4.5071 \\
(1.723)\end{array}$ & $\begin{array}{l}.02172 \\
(0.006)\end{array}$ \\
\hline State-Industry Wage & $\begin{array}{l}.00049 \\
(2.824)\end{array}$ & $\begin{array}{l}.00047 \\
(2.095)\end{array}$ & $\begin{array}{l}.00066 \\
(3.594)\end{array}$ & $\begin{array}{l}.00072 \\
(2.999)\end{array}$ \\
\hline $\begin{array}{l}\text { Proximity: } \\
\text { Mexico City }\end{array}$ & $\begin{array}{r}-.00053 \\
(-1.220)\end{array}$ & $\begin{array}{l}-.00038 \\
(-0.753)\end{array}$ & $\begin{array}{l}-.00068 \\
(-1.409)\end{array}$ & $\begin{array}{l}-.00056 \\
(-0.975)\end{array}$ \\
\hline $\begin{array}{c}\text { Proximity: } \\
\text { Mexico City }\end{array}$ & $\begin{array}{r}.0000 \\
(0.761)\end{array}$ & $\begin{array}{r}.0000 \\
(0.685)\end{array}$ & $\begin{array}{r}.0000 \\
(1.179)\end{array}$ & $\begin{array}{r}.0000 \\
(1.274)\end{array}$ \\
\hline Proximity: USA & $\begin{array}{l}.00164 \\
(1.562)\end{array}$ & $\begin{array}{l}.00204 \\
(1.682)\end{array}$ & $\begin{array}{r}.00085 \\
(0.720)\end{array}$ & $\begin{array}{r}.00074 \\
(0.522)\end{array}$ \\
\hline Proximity: $\mathrm{USA}^{2}$ & $\begin{array}{r}-.0000 \\
(-1.292)\end{array}$ & $\begin{array}{r}-.0000 \\
(-1.352)\end{array}$ & $\begin{array}{r}-.0000 \\
(-0.730)\end{array}$ & $\begin{array}{r}-.0000 \\
(-0.266)\end{array}$ \\
\hline Relative Plant Size & $\begin{array}{r}.43054 \\
(10.676)\end{array}$ & $\begin{array}{l}.44669 \\
(8.895)\end{array}$ & $\begin{array}{r}.48078 \\
(11.000)\end{array}$ & $\begin{array}{l}.52797 \\
(9.483)\end{array}$ \\
\hline Maquila Dummy & $\begin{array}{l}.06989 \\
(0.633)\end{array}$ & $\begin{array}{l}-.04539 \\
(-0.328)\end{array}$ & $\begin{array}{r}.01759 \\
(0.152)\end{array}$ & $\begin{array}{r}-.09295 \\
(-0.635)\end{array}$ \\
\hline Value Added Taxes & $\begin{array}{l}.70541 \\
(1.066)\end{array}$ & $\begin{array}{l}1.1193 \\
(1.381)\end{array}$ & $\begin{array}{l}.56852 \\
(0.860)\end{array}$ & $\begin{array}{l}.90044 \\
(1.107)\end{array}$ \\
\hline Royalty Payments & $\begin{array}{r}10.8846 \\
(3.851)\end{array}$ & $\begin{array}{l}6.0466 \\
(1.668)\end{array}$ & $\begin{array}{l}10.9750 \\
(3.827)\end{array}$ & $\begin{array}{r}5.0939 \\
(1.307)\end{array}$ \\
\hline No. of Observations & 4149 & 2991 & 3789 & 2687 \\
\hline Log Likelihood & -1971.58 & -1282.15 & -1766.68 & -1107.55 \\
\hline
\end{tabular}




\begin{tabular}{|c|c|c|c|c|}
\hline & \multicolumn{2}{|c|}{ All Industries } & \multicolumn{2}{|c|}{ Excluding Natural Resources } \\
\hline & $\begin{array}{r}\text { All Plants } \\
(1) \\
\end{array}$ & $\begin{array}{r}\text { Domestic } \\
\text { Only (2) } \\
\end{array}$ & $\begin{array}{r}\text { All Plants } \\
(3) \\
\end{array}$ & $\begin{array}{r}\text { Domestic } \\
\text { Only (4) } \\
\end{array}$ \\
\hline $\begin{array}{l}\text { Overall Industry } \\
\text { Concentration (lag) }\end{array}$ & $\begin{array}{r}-.13745 \\
(-2.140)\end{array}$ & $\begin{array}{r}-.10934 \\
(-1.399)\end{array}$ & $\begin{array}{l}-.16728 \\
(-2.382)\end{array}$ & $\begin{array}{r}-.1489 \\
(-1.700)\end{array}$ \\
\hline $\begin{array}{r}\text { Local Export } \\
\text { Concentration (lag) }\end{array}$ & $\begin{array}{l}.00941 \\
(2.544)\end{array}$ & $\begin{array}{l}.01067 \\
(2.563)\end{array}$ & $\begin{array}{l}.00757 \\
(1.200)\end{array}$ & $\begin{array}{l}.01109 \\
(1.554)\end{array}$ \\
\hline $\begin{array}{l}\text { MNE Export } \\
\text { Activity (lag) }\end{array}$ & $\begin{array}{l}.04768 \\
(2.471)\end{array}$ & $\begin{array}{l}.04778 \\
(2.216)\end{array}$ & $\begin{array}{l}.13392 \\
(2.740)\end{array}$ & $\begin{array}{l}.18374 \\
(2.760)\end{array}$ \\
\hline Plant FDI: USA & $\begin{array}{l}.91049 \\
(6.462)\end{array}$ & & $\begin{array}{r}1.0056 \\
(6.775)\end{array}$ & \\
\hline Plant FDI: Europe & $\begin{array}{l}.25854 \\
(1.075)\end{array}$ & & $\begin{array}{r}.26672 \\
(1.051)\end{array}$ & \\
\hline Plant FDI: Japan & $\begin{array}{l}.79207 \\
(1.393)\end{array}$ & & $\begin{array}{r}1.1961 \\
(1.946)\end{array}$ & \\
\hline Plant FDI: Other & $\begin{array}{l}.64543 \\
(3.320)\end{array}$ & & $\begin{array}{l}.68115 \\
(3.290)\end{array}$ & \\
\hline Domestic Price & $\begin{array}{r}.22323 \\
(0.924)\end{array}$ & $\begin{array}{l}-.07792 \\
(-0.259)\end{array}$ & $\begin{array}{r}-.02967 \\
(-0.115)\end{array}$ & $\begin{array}{r}-.37523 \\
(-1.163)\end{array}$ \\
\hline $\begin{array}{r}\text { Tariffs on Output } \\
\text { (TR1) }\end{array}$ & $\begin{array}{l}-.11756 \\
(-4.654)\end{array}$ & $\begin{array}{l}-.11624 \\
(-3.923)\end{array}$ & $\begin{array}{l}-.16836 \\
(-5.273)\end{array}$ & $\begin{array}{l}-.16548 \\
(-4.080)\end{array}$ \\
\hline $\begin{array}{r}\text { Quotas on Output } \\
\text { (TR2) }\end{array}$ & $\begin{array}{l}.00947 \\
(0.665)\end{array}$ & $\begin{array}{l}-.00444 \\
(-0.168)\end{array}$ & $\begin{array}{l}-.00252 \\
(-0.103)\end{array}$ & $\begin{array}{l}.00089 \\
(0.026)\end{array}$ \\
\hline $\begin{array}{r}\text { Tariffs on Inputs } \\
\text { (TR3) }\end{array}$ & $\begin{array}{l}.26276 \\
(3.652)\end{array}$ & $\begin{array}{l}.17332 \\
(1.908)\end{array}$ & $\begin{array}{r}.20423 \\
(2.711)\end{array}$ & $\begin{array}{l}.13498 \\
(1.392)\end{array}$ \\
\hline $\begin{array}{r}\text { Quotas on Inputs } \\
\text { (TR4) }\end{array}$ & $\begin{array}{l}-.02888 \\
(-1.438)\end{array}$ & $\begin{array}{l}-.03437 \\
(-1.407)\end{array}$ & $\begin{array}{l}-.10978 \\
(-3.878)\end{array}$ & $\begin{array}{l}-.12726 \\
(-3.770)\end{array}$ \\
\hline TR1 ${ }^{*} \mathrm{TR} 2$ & $\begin{array}{l}-.00047 \\
(-0.496)\end{array}$ & $\begin{array}{l}.00029 \\
(0.159)\end{array}$ & $\begin{array}{l}.00064 \\
(0.414)\end{array}$ & $\begin{array}{r}.00043 \\
(0.194)\end{array}$ \\
\hline TR3*TR4 & $\begin{array}{r}.00118 \\
(0.691)\end{array}$ & $\begin{array}{r}.00180 \\
(0.843)\end{array}$ & $\begin{array}{c}.00613 \\
(2.935)\end{array}$ & $\begin{array}{l}.00753 \\
(3.009)\end{array}$ \\
\hline $\begin{array}{r}\text { Construction Price } \\
\text { Index }\end{array}$ & $\begin{array}{r}-50.0385 \\
(-2.322)\end{array}$ & $\begin{array}{l}-33.845 \\
(-1.188)\end{array}$ & $\begin{array}{l}-74.089 \\
(-3.117)\end{array}$ & $\begin{array}{r}-58.6058 \\
(-1.834)\end{array}$ \\
\hline
\end{tabular}




\begin{tabular}{|c|c|c|c|c|}
\hline & \multicolumn{2}{|c|}{ All Industries } & \multicolumn{2}{|c|}{ Excluding Natural Resources } \\
\hline & $\begin{array}{r}\text { All Plants } \\
\text { (1) }\end{array}$ & $\begin{array}{r}\text { Domestic } \\
\text { Only (2) }\end{array}$ & $\begin{array}{r}\text { All Plants } \\
\text { (3) }\end{array}$ & $\begin{array}{r}\text { Domestic } \\
\text { Only (4) }\end{array}$ \\
\hline $\begin{array}{r}\text { Machinery Price } \\
\text { Index }\end{array}$ & $\begin{array}{l}-.44826 \\
(-0.535)\end{array}$ & $\begin{array}{l}-.30834 \\
(-0.290)\end{array}$ & $\begin{array}{l}-.97062 \\
(-1.001)\end{array}$ & $\begin{array}{r}-.39259 \\
(-0.302)\end{array}$ \\
\hline $\begin{array}{r}\text { Transportation Price } \\
\text { Index }\end{array}$ & $\begin{array}{l}1.5864 \\
(1.940)\end{array}$ & $\begin{array}{l}1.9560 \\
(2.118)\end{array}$ & $\begin{array}{l}3.3132 \\
(3.509)\end{array}$ & $\begin{array}{l}3.8408 \\
(3.450)\end{array}$ \\
\hline $\begin{array}{l}\text { Office Equipment } \\
\text { Price Index }\end{array}$ & $\begin{array}{l}-5.0498 \\
(-3.537)\end{array}$ & $\begin{array}{l}-5.0583 \\
(-3.008)\end{array}$ & $\begin{array}{l}-2.2131 \\
(-1.291)\end{array}$ & $\begin{array}{l}-2.3283 \\
(-1.123)\end{array}$ \\
\hline $\begin{array}{r}\text { Raw Material Price } \\
\text { Index }\end{array}$ & $\begin{array}{l}.40106 \\
(1.341)\end{array}$ & $\begin{array}{l}.67316 \\
(1.762)\end{array}$ & $\begin{array}{l}.03126 \\
(0.098)\end{array}$ & $\begin{array}{l}.18406 \\
(0.414)\end{array}$ \\
\hline $\begin{array}{r}\text { Electricity Price } \\
\text { Index }\end{array}$ & $\begin{array}{r}25.473 \\
(2.300)\end{array}$ & $\begin{array}{r}17.015 \\
(1.166)\end{array}$ & $\begin{array}{r}37.221 \\
(3.050)\end{array}$ & $\begin{array}{l}28.769 \\
(1.757)\end{array}$ \\
\hline State-Industry Wage & $\begin{array}{l}.00050 \\
(2.331)\end{array}$ & $\begin{array}{l}.00052 \\
(1.913)\end{array}$ & $\begin{array}{l}.00051 \\
(2.249)\end{array}$ & $\begin{array}{l}.00057 \\
(1.923)\end{array}$ \\
\hline $\begin{array}{r}\text { Proximity: } \\
\text { Mexico City }\end{array}$ & $\begin{array}{l}-.00062 \\
(-1.033)\end{array}$ & $\begin{array}{l}-.00045 \\
(-0.655)\end{array}$ & $\begin{array}{l}-.00061 \\
(-0.900)\end{array}$ & $\begin{array}{r}-.00040 \\
(-0.504)\end{array}$ \\
\hline $\begin{array}{l}\text { Proximity: } \\
\text { Mexico City }\end{array}$ & $\begin{array}{r}.0000 \\
(0.459)\end{array}$ & $\begin{array}{r}.0000 \\
(0.415)\end{array}$ & $\begin{array}{r}.0000 \\
(0.670)\end{array}$ & $\begin{array}{r}.0000 \\
(0.643)\end{array}$ \\
\hline Proximity: USA & $\begin{array}{r}.00037 \\
(0.252)\end{array}$ & $\begin{array}{l}.00096 \\
(0.576)\end{array}$ & $\begin{array}{l}.00034 \\
(0.196)\end{array}$ & $\begin{array}{l}.00054 \\
(0.267)\end{array}$ \\
\hline Proximity: USA ${ }^{2}$ & $\begin{array}{r}-.0000 \\
(-0.0840\end{array}$ & $\begin{array}{r}-.0000 \\
(-0.456)\end{array}$ & $\begin{array}{r}-.0000 \\
(-0.312)\end{array}$ & $\begin{array}{r}-.0000 \\
(-0.241)\end{array}$ \\
\hline Relative Plant Size & $\begin{array}{l}.48188 \\
(8.172)\end{array}$ & $\begin{array}{l}.48664 \\
(6.778)\end{array}$ & $\begin{array}{r}.56661 \\
(8.658)\end{array}$ & $\begin{array}{r}.61307 \\
(7.507)\end{array}$ \\
\hline Maquila Dummy & $\begin{array}{l}.11851 \\
(0.792)\end{array}$ & $\begin{array}{l}.00198 \\
(0.011)\end{array}$ & $\begin{array}{r}.08133 \\
(0.517)\end{array}$ & $\begin{array}{l}-.02038 \\
(-0.106)\end{array}$ \\
\hline Value Added Taxes & $\begin{array}{r}1.0649 \\
(1.200)\end{array}$ & $\begin{array}{r}1.8278 \\
(1.461)\end{array}$ & $\begin{array}{r}1.0212 \\
(1.117)\end{array}$ & $\begin{array}{r}1.6576 \\
(1.3010\end{array}$ \\
\hline Royalty Payments & $\begin{array}{l}10.070 \\
(2.551)\end{array}$ & $\begin{array}{r}6.3971 \\
(1.328)\end{array}$ & $\begin{array}{r}9.7359 \\
(2.342)\end{array}$ & $\begin{array}{r}3.8113 \\
(0.737)\end{array}$ \\
\hline No. of Observations & 2078 & 1499 & 1898 & 1347 \\
\hline Log Likelihood & -1033.40 & -701.34 & -906.89 & -593.267 \\
\hline
\end{tabular}




\begin{tabular}{|c|c|c|c|c|}
\hline \multirow{3}{*}{$\begin{array}{r}\text { (All variables in first } \\
\text { differences) }\end{array}$} & \multicolumn{4}{|c|}{$\begin{array}{l}\text { Table 7: Fixed-Effect Logit Estimation } \\
\text { (asymptotic t-statistics in parentheses) }\end{array}$} \\
\hline & \multicolumn{2}{|c|}{ All Industries } & \multicolumn{2}{|c|}{$\begin{array}{l}\text { Excluding Natural } \\
\text { Resource Industries }\end{array}$} \\
\hline & All Plants & Domestic Only & All Plants & Domestic Only \\
\hline $\begin{array}{r}\text { Overall Industry } \\
\text { Concentration }\end{array}$ & $\begin{array}{r}.03799 \\
(0.095)\end{array}$ & $\begin{array}{r}.25278 \\
(0.237)\end{array}$ & $\begin{array}{l}-.07942 \\
(-0.172)\end{array}$ & $\begin{array}{l}-.31887 \\
(-0.284)\end{array}$ \\
\hline $\begin{array}{l}\text { Local Export } \\
\text { Concentration }\end{array}$ & $\begin{array}{r}-.00924 \\
(-0.310)\end{array}$ & $\begin{array}{l}-.01111 \\
(-0.310)\end{array}$ & $\begin{array}{r}-.04065 \\
(-0.860)\end{array}$ & $\begin{array}{r}-.04499 \\
(-0.889)\end{array}$ \\
\hline MNE Export Activity & $\begin{array}{l}.06662 \\
(1.506)\end{array}$ & $\begin{array}{r}1.23479 \\
(1.946)\end{array}$ & $\begin{array}{l}.04059 \\
(0.567)\end{array}$ & $\begin{array}{r}1.6434 \\
(2.134)\end{array}$ \\
\hline Domestic Price & $\begin{array}{l}1.6276 \\
(0.789)\end{array}$ & $\begin{array}{r}1.56197 \\
(0.628)\end{array}$ & $\begin{array}{l}1.8748 \\
(0.840)\end{array}$ & $\begin{array}{l}2.0412 \\
(0.768)\end{array}$ \\
\hline Tariffs on Output (TR1) & $\begin{array}{l}-.01906 \\
(-0.548)\end{array}$ & $\begin{array}{r}-.03846 \\
(-0.849)\end{array}$ & $\begin{array}{r}.01363 \\
(0.346)\end{array}$ & $\begin{array}{l}.02078 \\
(0.383)\end{array}$ \\
\hline Quotas on Output (TR2) & $\begin{array}{l}-.01271 \\
(-0.719)\end{array}$ & $\begin{array}{r}-.01480 \\
(-0.636)\end{array}$ & $\begin{array}{r}-.00474 \\
(-0.240)\end{array}$ & $\begin{array}{l}.00278 \\
(0.112)\end{array}$ \\
\hline Tariffs on Inputs (TR3) & $\begin{array}{r}.03743 \\
(0.506)\end{array}$ & $\begin{array}{l}.11868 \\
(1.319)\end{array}$ & $\begin{array}{r}.06053 \\
(0.716)\end{array}$ & $\begin{array}{l}.11815 \\
(1.208)\end{array}$ \\
\hline Quotas on Inputs (TR4) & $\begin{array}{r}.01289 \\
(0.397)\end{array}$ & $\begin{array}{r}.01407 \\
(0.416)\end{array}$ & $\begin{array}{l}.01769 \\
(0.496)\end{array}$ & $\begin{array}{l}.02696 \\
(0.683)\end{array}$ \\
\hline $\mathrm{TR} 1 * \mathrm{TR} 2$ & $\begin{array}{l}.00022 \\
(0.432)\end{array}$ & $\begin{array}{l}.00015 \\
(0.245)\end{array}$ & $\begin{array}{l}-.00002 \\
(-0.036)\end{array}$ & $\begin{array}{l}-.00018 \\
(-0.282)\end{array}$ \\
\hline TR3*TR4 & $\begin{array}{l}.00044 \\
(0.302)\end{array}$ & $\begin{array}{r}.00048 \\
(0.312)\end{array}$ & $\begin{array}{r}.0008 \\
(0.500)\end{array}$ & $\begin{array}{l}.00053 \\
(0.290)\end{array}$ \\
\hline $\begin{array}{r}\text { Construction Price } \\
\text { Index }\end{array}$ & $\begin{array}{r}8.0499 \\
(0.268)\end{array}$ & $\begin{array}{r}52.188 \\
(0.767)\end{array}$ & $\begin{array}{r}5.5247 \\
(0.175)\end{array}$ & $\begin{array}{r}40.4065 \\
(0.590)\end{array}$ \\
\hline $\begin{array}{r}\text { Machinery Price } \\
\text { Index }\end{array}$ & $\begin{array}{l}4.9528 \\
(1.613)\end{array}$ & $\begin{array}{r}4.1286 \\
(0.962)\end{array}$ & $\begin{array}{l}4.6893 \\
(1.402)\end{array}$ & $\begin{array}{r}3.751 \\
(0.840)\end{array}$ \\
\hline $\begin{array}{r}\text { Transportation Price } \\
\text { Index }\end{array}$ & $\begin{array}{r}.69577 \\
(0.278)\end{array}$ & $\begin{array}{r}-.24304 \\
(-0.086)\end{array}$ & $\begin{array}{r}-.36272 \\
(-0.149)\end{array}$ & $\begin{array}{r}-.6789 \\
(-0.245)\end{array}$ \\
\hline $\begin{array}{r}\text { Office Equipment Price } \\
\text { Index }\end{array}$ & $\begin{array}{r}19.4978 \\
(0.931)\end{array}$ & $\begin{array}{c}33.354 \\
(1.295)\end{array}$ & $\begin{array}{r}13.262 \\
(0.612)\end{array}$ & $\begin{array}{r}17.4005 \\
(0.686)\end{array}$ \\
\hline $\begin{array}{r}\text { Raw Material Price } \\
\text { Index }\end{array}$ & $\begin{array}{l}4.1226 \\
(1.580)\end{array}$ & $\begin{array}{l}4.5246 \\
(1.299)\end{array}$ & $\begin{array}{r}2.2816 \\
(0.833)\end{array}$ & $\begin{array}{r}1.4393 \\
(0.400)\end{array}$ \\
\hline
\end{tabular}




\begin{tabular}{|c|c|c|c|c|}
\hline \multirow{2}{*}{$\begin{array}{r}\text { (All variables in first } \\
\text { differences) }\end{array}$} & \multicolumn{2}{|c|}{ All Industries } & \multicolumn{2}{|c|}{ Excluding Natural Resources } \\
\hline & All Plants & Domestic Only & All Plants & Domestic Only \\
\hline State-Industry Wage & $\begin{array}{l}.00017 \\
(0.167)\end{array}$ & $\begin{array}{l}-.00041 \\
(-0.238)\end{array}$ & $\begin{array}{r}.00033 \\
(0.293)\end{array}$ & $\begin{array}{l}.00065 \\
(0.305)\end{array}$ \\
\hline Relative Plant Size & $\begin{array}{r}-.2871 \\
(-0.382)\end{array}$ & $\begin{array}{r}-.34367 \\
(-0.319)\end{array}$ & $\begin{array}{r}-.05695 \\
(-0.072)\end{array}$ & $\begin{array}{l}-.27633 \\
(-0.234)\end{array}$ \\
\hline Maquila Dummy & $\begin{array}{l}-1.0942 \\
(-1.698)\end{array}$ & $\begin{array}{r}-1.46388 \\
(-1.911)\end{array}$ & $\begin{array}{l}-1.1549 \\
(-1.668)\end{array}$ & $\begin{array}{l}-1.4443 \\
(-1.709)\end{array}$ \\
\hline Value Added Taxes & $\begin{array}{r}2.5522 \\
(0.454)\end{array}$ & $\begin{array}{l}.31651 \\
(0.165)\end{array}$ & $\begin{array}{r}5.9465 \\
(0.952)\end{array}$ & $\begin{array}{l}.62044 \\
(0.216)\end{array}$ \\
\hline Royalty Payments & $\begin{array}{l}11.379 \\
(0.655)\end{array}$ & $\begin{array}{r}34.8567 \\
(1.330)\end{array}$ & $\begin{array}{r}12.7548 \\
(0.745)\end{array}$ & $\begin{array}{l}27.044 \\
(1.003)\end{array}$ \\
\hline No. of Observations & 245 & 160 & 227 & 143 \\
\hline Log Likelihood & -63.72 & -41.96 & -56.27 & -37.38 \\
\hline
\end{tabular}




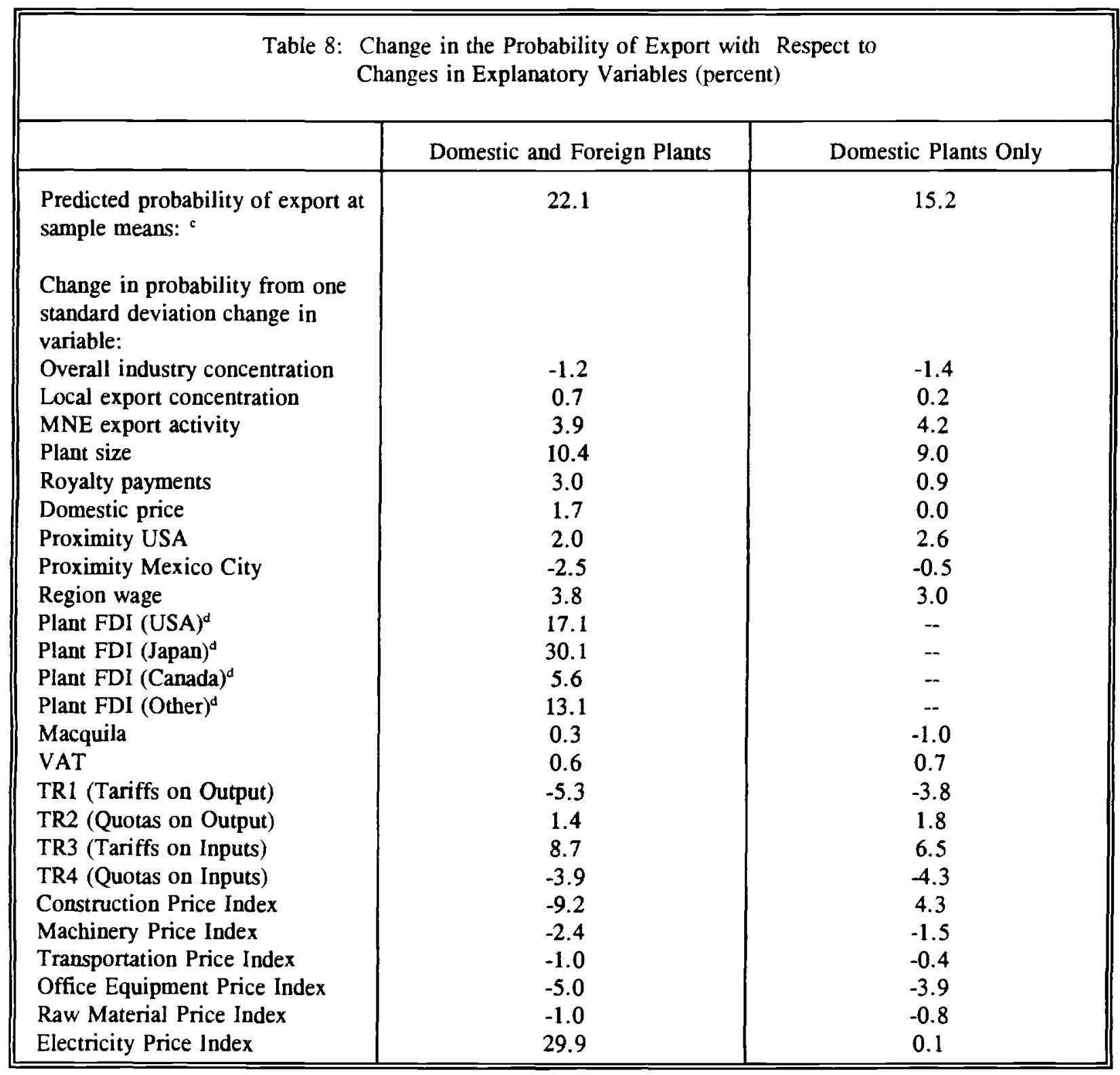

- Corresponds to the regression in column (3) of Table 5.

b Corresponds to the regression in column (4) of Table 5.

c Including regional and industry dummy variables not shown.

d Change in independent variable from zero to one. 